\title{
FROM BIOECONOMIES TO BIOECONOPYSIS IN THE CONTEXT OF [BIO]DIVERSITY AND MODERN MORALITY
}

\author{
Yuichi Tei/ Ung-Il Chung ${ }^{1}$ and Gheorghe Săvoiu ${ }^{2 *}$ \\ ${ }^{1)}$ University of Tokyo, Tokyo, Japan \\ 2) Univerity of Piteşti, Piteşti, Romania
}

Please cite this article as:

Tei, Y., / Chung, U. and Săvoiu, G., 2018. From Bioeconomics to Bioeconopysis in the Context of (Bio)Diversity and Modern Morality. Amfiteatru Economic, 20(49), pp. 754-770.

\section{Article History}

Received: 15 March 2018

Revised: 6 May 2018

Accepted: 14 June 2018

DOI: 10.24818/EA/2018/49/754

\begin{abstract}
The article develops a complex interdisciplinary paradigm, or rather a multiparadigm of bioeconomics, exemplifying the necessary role and the broader horizon of multidisciplinarity through bioeconophysics, in the context of (bio)diversity and modern morality, in a logically investigative and coherently summarized approach. A brief conceptual introduction is followed by the first section, dedicated to identifying the actual approach, going from scientific unidisciplinarity to modern multidisciplinarity, selecting and validating, out of the three hypotheses of plausible paths towards bioeconomics (BioEconoPhysics), Biophysical Economics or EconoBioPhysics, the one appropriately supported by arguments and historically motivated, but also because of the clarity of the methods and the consistency of the specific models. A second important section of the paper outlines the current context of (bio)diversity and morality, which is specific to bioeconomics, biophysics or econophysics, as well as the result of their interstitial or multidisciplinary unification, proving the usefulness of some detailed characteristic modern tendencies, relating to the opinions of, and relationships of science with ethics. Some final remarks and perspectives of econobiophysics or bioeconomics symmetrically close the outline of the article.
\end{abstract}

Keywords: bioeconomics, bioeconomy, biophysics, econophysics, bioeconophysics, economic biophysics, econobiophysics, economics, thermodynamics, (bio)diversity, morality, inter- and multidisciplinarity.

JEL Classification: A12, B29, N01, Q57, I23, Y80

* Corresponding author, Gheorghe Săvoiu - gsavoiu@ yahoo.com 


\section{Introduction}

Scientific disciplines have the ability to order the knowledge and data in a rigorously delineated field for the purpose of training students in schools and universities, finally defining a social and cognitive unity of knowledge production (Stichweh, 2001), and are a relatively recent invention of society as compared to sciences, whose past is millenniumold, and whose own areas are redefined continuously, through reunion and disciplinary interconnection. Any academic scientific discipline co-evolves with occupational and professional systems, and naturally observes the contours of academic departments, creating and maintaining disciplinary communities (Pierce, 1991), motivating, characterizing, classifying, specializing and ranking related individuals (disciples), or even disqualifying them, or invalidating their skills (Foucault, 1977).

Disciplines have been, and still remain, unidirectional or isolating, as well as relatively conflictual, while sciences, simultaneously distinctive and integrative, and at the same time both investigational and interpretative by their specific methods and models in relation to an object of study extracted from reality and independently theorized, feature a higher level of harmony and a broader intention, proven practically by co-habitation in standardized forms through trans-, inter-, cross- and multidisciplinarity (Săvoiu, Dinu, Tăchiciu, 2014; Dinu, Săvoiu, Dabija, 2016). As a mere example, academic disciplines such as statistical physics and quantum mechanics can be in a state of confrontation and mutual inadequacy, while the autonomy of a discipline like European economics can in turn be just an illusion. In direct contrast, the science of biology actively and intensively cooperates with physics in the interstitial space of modern biophysics, as proof of another type of appetite of sciences compared to the disciplines that make them up.

In the interdisciplinary and, later on, multidisciplinary conferences held since 2008, the year when the first BioPhysical Economics International Symposium was conducted in Syracuse, USA, till 2016, when the 7th symposium was held in Washington (Libbs, 2016), a distinct field of scientific investigation of the common species and human system has been more clearly delineated, continuously expanding their interstitium. Economic biophysics (physical bieconomy, or eco-bio-physics) is continuously amplifying its subject of study, capitalizing on the study of material and energy flows from the ecosystem perspective, and applying the results of that perspective in an attempt to understand the economy by means of physical methods and models, dominated by the logic of biophysics and less so through purely social thinking (BP Economics, 2018). Confirming the stages of the inter- and multidisciplinary making of economic biophysics requires a careful historical analysis, centered on creative taxonomies, in a temporal universe that is at least secular.

After a brief introduction, the investigative content of this original study demands, first of all, writing a section devoted to identifying the actual approach, from scientific unidisciplinarity to modern multidisciplinarity. The target is initially descriptive and subsequently selective, ultimately choosing, in a manner that is causally supported by arguments, and historically motivated through a validation process, out of a set of three hypotheses of plausible paths towards BioEconoPhysics, BioPhysical Economics or EconoBioPhysics, the one with a more realistic future, detailing the characteristic trends, but also due to the clarity of the methods and consistency of the characteristic models, which give substance to interdisciplinaryism and gradually extend it to multidisciplinarity. At the same time, another section briefly outlines the current context of (bio)diversity and morality, specific to bioeconomics, biophysics or econophysics, as well as the outcome of 
the initially interstitial, and, ultimately, multidisciplinary unification with respect to the relations of science and ethics. Several conclusions reveal the prospects of economic biphysics, eco-bio-physics or bioeconophysics, and give a necessary and creative outline to the final option.

\section{Three hypotheses in the foray going from BioEconophysics to BioPhysical Economics or EconoBioPhysics}

A conceptual, paradigmatic and taxonomic approach from bioeconomics to bioeconophysics (economic biophysics or econobiophysics) can be conducted setting out from as many as three originating sources or original landmarks, all of which are initially interdisciplinary or generating interstitia between two sciences and their essential theories: bioeconomy or bioeconomics (biology and economics), biophysics (biology and physics) and econophysics (economics and physics).

The meanings and derived implications of bioeconomics have gradually multiplied, revealing an evolutionary and stagial process, starting from a premise of the integrated interpretation of theory and pragmatism specific to science, as anticipated by Avicenna (Ibn-Sina) in the Poem of Medicine. The Canon of Medical Science; he was the first to divide science into theoretical understanding and practical action, while underlining that this principle did not mean that part of science (he was referring to medicine and, implicitly, biology) should be seen as knowledge, and the other part as action (Avicenna, 1962, p. 112). The same stage-oriented, evolutionary and aggregative type of thinking also generated the evolution of bioeconomics from interdisciplinarity to multidisciplinarity, that science providing a better knowledge of the state of human society by integrating its theoretical bases with the way they are applied (the pragmatic or economic action of biological theory). In 1377, Ibn-Haldun conceptualized the economy in a modern way, in his Muqaddimah or Prolegomena, through a genuine, accurate description of phased growth processes: "When a population grows, the available labour is subject to new growth, and the need for luxuries is growing in correspondence with growing revenues, as well as with the habits and needs of luxuries. The value accumulated by luxury products results in other increases, and the revenues are again multiplied... And so there occurs an increase of the second and third level" (Ibn-Khaldun, 1969). In parallel with the economic process, Ibn-Khaldun also described a biological process similar to that by which "species become more numerous", and he eventually anticipated even the biological theory of evolution. The association of the economy with biology, in the profoundness of Ibn-Khaldun's thought, had as a natural premise the similarity of the analyzed populations and their growth processes, along with the biological premise of the integration of theory and pragmatism.

The term bioeconomics was first used by British biologist Hermann Reinheimer in 1913, in his book Evolution by Co-operation: A Study in Bio-economics. In this book, the author described how different living organisms secure their living within nature's own economy. The meaning he gave to bioeconomics is a generalized one, and cannot be profoundly associated with its modern meanings (Reinheimer, 1913, p. 200). Less than a decade later, another assignment of terminological paternity can be identified for bioeconomics, which points to F.I. Baranoff, whose concept is ambivalent, i.e. bionomics or bio-economics, thus underlining the essence of an optimal biological solution to the issue of overfishing in economic terms. In this second variant one recognizes a significant contemporary 
significance of bioeconomics, starting from the way it was conceptualized by F. I. Baranoff, between 1918 and 1925, and capitalizing on a sense that is in a much closer relation to the modern meaning, i.e., the sum of activities based on bio-resources (from the products of terrestrial or marine life, plants, animals, bacteria, etc.), by identifying theories and practices that allow an economic approach to biological behaviours (Baranoff, 1918; 1925). In this initial concept and acceptation of bioeconomics as biological economics, there are two causes that enclose and conceal the major historical tendencies of the emergence of the concept as such (Gordon, 1991):

- the lack of theoretical economic research in important biological domains, resulting in the interstitial expansion of biology in the study area characteristic of biology (Gerhardsen, 1952); in some cases the science of biology managed to penetrate into bioeconomics in depth, even in a determinant manner, though failing to possess the analytical tools of economic theory (Nesbit, 1943; Burkenroad, 1951; Taylor, 1951);

- recognizing and capitalizing on the theory of biology by economic science research, "management or administration of fisheries being destined for humans, rather than fish or ecology" (Burkenroad, 1953), thus emphasizing the special attention that has to go to the economic aspects of a biological problem or to economic research in biology (bioeconomy).

Essentially, the beginning or inception is interdisciplinary (inbetween disciplines), but the goal of bioeconomics gradually becomes one of a multidisciplinary type (Săvoiu, 2015, p. 30), assimilable to the transition from a simple paradigm to a complex paradigm (Figure no. 1).

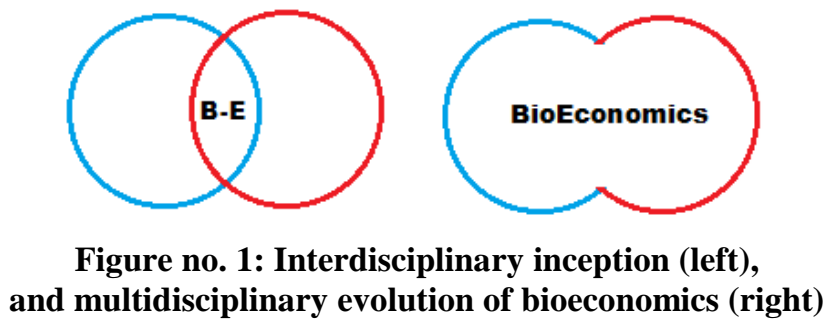

The multidisciplinarity of the vision of biology and economics within bioeconomics has gradually become a reality at the level of a living organism such as that of human society, and the multiplication of modern meanings and implications has become its natural consequence (Figure no. 2).

Over time, bioeconomics has generated one of the most important interdisciplinary economic schools, which started under the influence of thermodynamics in Nicholas Georgescu-Roegen's bioeconomic theory in the mid-20th century, and it became increasingly active in the $21^{\text {st }}$ century. Bioeconomics has been based on the paradigm of complex multidisciplinarity, being positioned, not only alphabetically but also chronologically or hierarchically, between the Austrian School and the Chicago School, on a long list, alongside the constitutional, evolutionary economics, Keynesian, Marxist and neo-Marxist economics, neo-Ricardianism, New Keynesian and post-Keynesian economy, the new school of classic macroeconomics, the Freiburg school, the school of public choice, the Lausanne school, the Stockholm school, the socio-physics school, the econophysics school, etc. (Săvoiu and Iorga, 2017). 


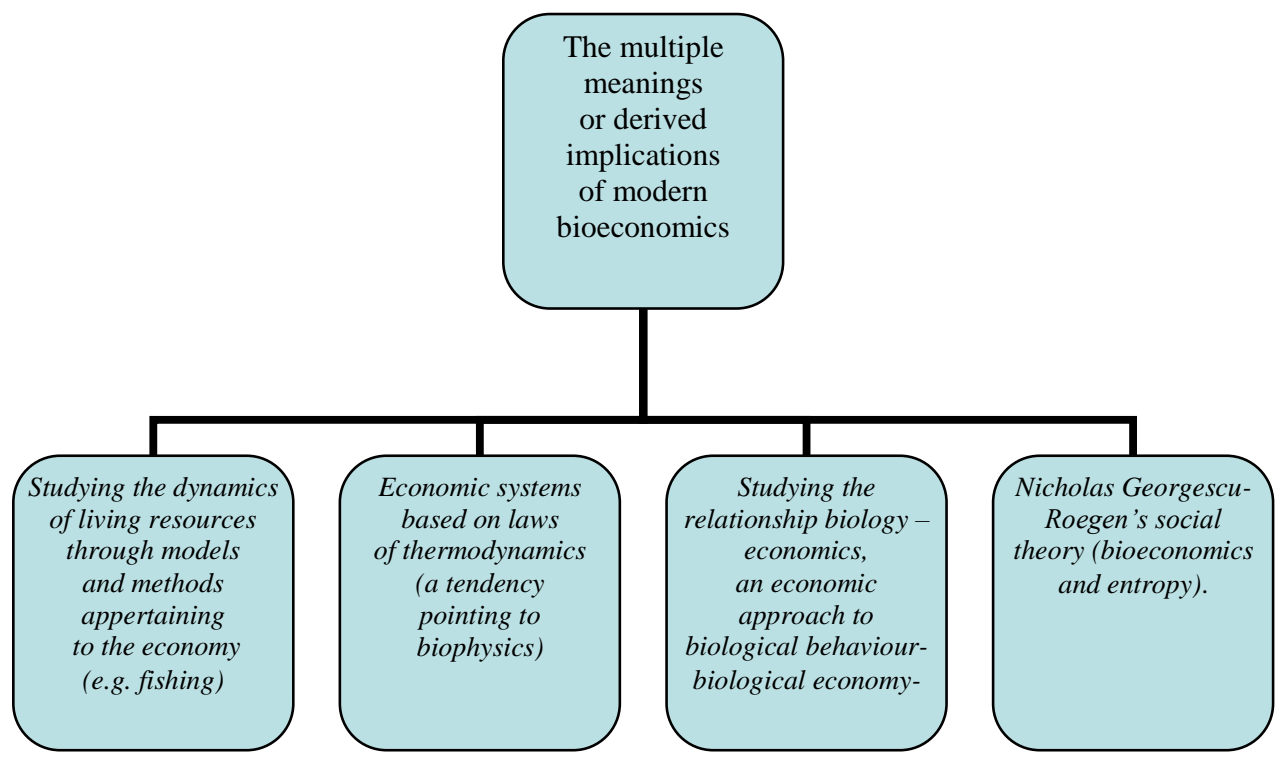

Figure no. 2: Conceptual variants in the modern bio-economics paradigm

Sources: Baranoff, 1918, 1925; Lotka, 1925; Georgescu-Roegen, 1971, 1977a, 1977b.

The recognized father of the bioeconomic school was the Romanian-born mathematician, statistician and economist Nicholas Georgescu-Roegen. If biology remains, in its simplest defining expression, the science of life, and if, internally and introspectively, economy is a component of life itself, then Georgescu-Roegen's bioeconomics intersects life with the economy, in an attempt to identify a number of specific processes in an isolated or closed interstitial space. Nicholas Georgescu-Roegen's pioneering conception was initially strictly biothermodynamic and applied in an exclusively economic universe, conceived as a closed adiabatic space (Georgescu-Roegen, 1971, 1977a, 1977b). Half a century after the moment Georgescu-Roegen exemplarily, though intuitively, discerned the content of bioeconomics, Juergen Mimkes was able to accurately identify many similarities that would inevitably transform thermodynamics and economics into bio-economics through interdisciplinarity (Table no. 1):

Table no. 1: Similarities of thermodynamics and economics that generated bioeconomics through interdisciplinarity

\begin{tabular}{|l|l|}
\hline \multicolumn{1}{|c|}{ Thermodynamics } & \multicolumn{1}{|c|}{ Economics } \\
\hline $\begin{array}{l}\text { 1. The general theory is applied in various } \\
\text { natural sciences, in physics, chemistry, } \\
\text { engineering, metallurgy, etc. }\end{array}$ & $\begin{array}{l}\text { 1. The general theory is applied in various } \\
\text { types of activities of nature, and physico- } \\
\text { chemical, engineering, metallurgical, etc. } \\
\text { activities }\end{array}$ \\
\hline $\begin{array}{l}\text { 2. The theory is based on two essential } \\
\text { parameters: temperature (T) and pressure } \\
(\mathrm{P})\end{array}$ & $\begin{array}{l}\text { 2. The economic theory depends on two } \\
\text { classical factors (parameters): capital (K) } \\
\text { and labour (L) }\end{array}$ \\
\hline
\end{tabular}




\begin{tabular}{|l|l|}
\hline \multicolumn{1}{|c|}{ Thermodynamics } & \multicolumn{1}{|c|}{ Economics } \\
\hline $\begin{array}{l}\text { 3. The theory is focused on the } \\
\text { calculation in two dimensions }\end{array}$ & $\begin{array}{l}\text { 3. The theory is quantified by accounting in } \\
\text { keeping with the principle of double record }\end{array}$ \\
\hline $\begin{array}{l}\text { 4. The theory and specific determinations } \\
\text { lead to two laws (principles) of } \\
\text { thermodynamics. }\end{array}$ & $\begin{array}{l}\text { 4. Accounting leads to equations } \\
\text { corresponding to the two laws of } \\
\text { thermodynamics. }\end{array}$ \\
\hline $\begin{array}{l}\text { 5. The Carnot process depends on two } \\
\text { temperatures, i.e. hot and cold. }\end{array}$ & $\begin{array}{l}\text { 5. Economic production is a two-level } \\
\text { Carnot process: revenue and costs }\end{array}$ \\
\hline $\begin{array}{l}\text { 6. Efficiency increases with the difference } \\
\text { in temperature. }\end{array}$ & $\begin{array}{l}\text { 6. Efficiency increases with the difference } \\
\text { between revenue and costs }\end{array}$ \\
\hline $\begin{array}{l}\text { 7.Essential symmetrical/equivalent } \\
\text { concepts }\end{array}$ & $\begin{array}{l}\text { 7.Essential symmetrical/equivalent concepts } \\
\text { A. Capital B. Surplus C. Function of } \\
\text { production D. Companies E. Banks, etc. }\end{array}$ \\
D. Engines E. Heat pumps, etc.
\end{tabular}

Source: Synthesis made by authors after Mimkes, 2016, p. 1.

Nicholas Georgescu-Roegen was considered to be the founder of modern bio-economics, primarily for having accurately and concretely identified the interstitium of thermodynamics and economics, apt to generate the bioeconomic theory. The emphasis on thermodynamics, otherwise present through entropy, in the very title of his major work, The Entropy Law and the Economic Process, opposed classical economic thinking through the bioeconomic school thus founded, which focused on the analysis of economic activities, similarly, and descending from, biological evolution, although with extrasomatic (cultural and social) means, achieving the necessary conciliation with ecology, starting from mathematically and physically substantiated arguments, which anticipated the future of bioeconomics. The ability of the human being, and ultimately even of the human species, to develop tools and create detachable organs or extensions of the human body, redefined as exosomatic organs, thus becomes a biological component of bioeconomics.

Axiomatically, entropy is found in Nicholas Georgescu-Roegen's bioeconomics through four essential classical principles, from which seven other modern principles were derived, as shown in table no. 2 .

Table no. 2: Principles present in Nicholas Georgescu-Roegen's bioeconomics

\begin{tabular}{|c|c|}
\hline $\begin{array}{l}\text { Classical (essential/paradoxical) } \\
\text { principles }\end{array}$ & Modern (derived/associated) principles \\
\hline \multirow{2}{*}{$\begin{array}{l}\text { 1. The qualitative changes caused by } \\
\text { the extensions of the human body } \\
\text { inevitably contribute to the stagnation } \\
\text { of the economy's progress, and the } \\
\text { degradation of the environment by } \\
\text { humans and the human species cancels } \\
\text { the economic process that sustains it; }\end{array}$} & $\begin{array}{l}\text { I. The technological optimism of the } \\
\text { economy is absolutely unreasonable and } \\
\text { unfounded }\end{array}$ \\
\hline & $\begin{array}{l}\text { II. Production involves the transformation of } \\
\text { a limited stock of raw materials and energy, } \\
\text { any economic growth is only apparent, that of } \\
\text { output per input, and implicitly a real entropic } \\
\text { degradation of energy resources. }\end{array}$ \\
\hline
\end{tabular}




\section{Classical (essential/paradoxical) principles}

2. The entropy of the closed economic system is continuously and irreversibly increasing to a maximum value, and the available energy becomes unavailable, up to the disappearance of economic growth through lack of correlation with the growing resource shortages (the principle of the lack of absolute substitutability in bioeconomics);

3. The expanded thermodynamic principle shows that matter is subject to the same degradation as energy (e.g. rubber, plastic);

4. Even when useful and efficient, no recycling system can stop the degradation of resources - at most it will slow it down.

\section{Modern (derived/associated) principles}

III. The Earth has limited resources and energy, and is not the property of a given generation

IV. The principle of conservation of resources and energy remains fundamental.

$\mathrm{V}$. The excesses and bioeconomic criminality of consumerism must be discouraged, and resources should become global, which includes human resources, which will never have a passport.

VI. Bioeconomic policies involve no risk, because the economic process is irreversible, and the historical variable is impossible to modify or adjust.

VII. Restriction of life focuses on exosomatic, short and tumultuous comfort, and the expansion of a more monotonous and long-lived lifestyle. The excessively structured and monopolized economic process has an ever-growing entropy.

Source: Principles synthesized by the authors after Miernyck, 1996; Mirowski, 1996; Demetrescu, 1996; Witt, 1999; McCormick and Kautto, 2013; Săvoiu and Iorga, 2017.

Another terminological origination, as an inter- and multidisciplinary outcome, was generated by Alfred Lotka, a pioneer of inter- and multidisciplinary research, in terms of both his diverse training as an excellent mathematician, chemist, physicist, statistician and demographer, and his proven creativity in analyzing the dynamics of the human population, as well as the originality of his solutions in the field of energy. Alfred Lotka's confirmation as a biophysicist is the natural consequence of the creation and development of the predatory-prey model, simultaneously, yet independently of Vito Volterra; the LotkaVolterra model still represents the basis of other models used in analyses of population dynamics in ecology.

In the preface to his Element of Physical Biology, published in 1925, on page VII, Alfred Lotka indicates some nuances and outlines of the new paradigm, in two systematically substructured notions, Physical Biology and Biophysics. The concept of Physical Biology was used by Alfred Lotka to "designate the scope of applying the physical principles and methods for examining biological systems," or "to apply physical principles to the study of life systems as a whole," while Biophysics covered "rather a special field of certain physical aspects of the individual's life", a structural sub-paradigm actually included in the scope of physical biology (Lotka, 1925).

Extrapolating the intersection of objectives and addressing it systemically, Alfred Lotka considered that Physical Biology is itself a subsystem or an essential branch of a wider multidisciplinary vision, which he called General Mechanics of Evolution, a type of global 
mechanics of the systems exposed to irreversible changes in the distribution of matter between their various components or subsystems.

This second terminological route defines, purely chronologically, through Biophysics, not only an interstitial space between biology and physics, but also an evolutionary interdisciplinary paradigm, originally dominated by the cross-disciplinarity of methods and even models, taken from physics into biology, in order to eventually describe a type of complex multidisciplinarity (Figure no. 3):
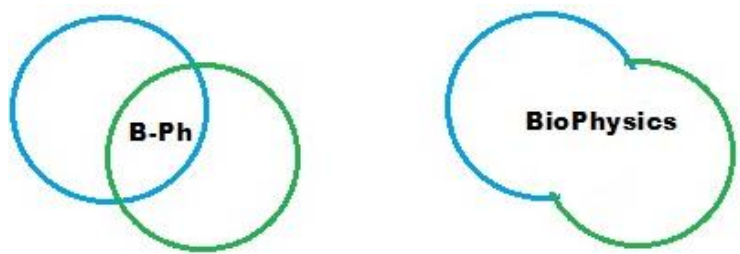

Figure no. 3: Interdisciplinary inception (left), and multidisciplinary evolution of biophysics (right)

Biophysics was the creative and necessary step for the emergence of the threedisiciplinarity of econometrics, whose complex significance as "unification of points of view referring to economic, statistical and mathematical theories concerning the nature of quantitative relations in the economy" became a highly visible way of thinking belonging to Ragnar Frisch, in the history of science, and was to expand interdisciplinarity towards the much wider space of multidisciplinarity (Frisch, 1933, p. 187). In the spirit of his extended biophysical thinking, Alfred Lotka also proposed quantifying natural selection through a physical law, starting from the selective principle of evolution that favours the utmost use of energy flow, which later became Lotka's law, or the principle of maximum power in ecology of ecosystems (Odum, 1971).

The beginnings of the interdisciplinary of economics and physics, without however generating the concept of the new science called econophysics (or EconoPhysics), representing the third universe of interdisciplinarity leading to bioeconophysics (or BioEconophysics), can be identified in Louis Bachelier's 1900 book, Théorie de la spéculation, where the author analyzed a Gaussian distribution of price changes (Bachelier, 1900), followed by Ettore Majorana's 1942 Valore delle statistiche leggi nella fisica e nelle scienze (Value of Statistic Laws in Physics and Science), which establishes the first essential analogies between the laws of statistical physics and economics and the approach to the economic processes through statistical physics, expanding into social sciences (Majorana, 1942).

The emergence of the concept as such and the neologization of the term econophysics are the work of Rosario Mantegna and Eugene Stanley, and occurred during the second physical physics conference in Kolkata, in 1995, when they also proposed the first definition of econophysics as a field or science, bringing together "the activities of the physicists who work with questions and problems of economics, in order to test a variety of new conceptual approaches deriving from the physical sciences" (Mantegna and Stanley, 2000). Initially, econophysical researches dealt with the distribution of profit on the financial market, the time correlation of the financial data series, the analogies and the differences between the price dynamics and the physical processes, through turbulences, the distribution of the economic stocks and the increase in the variation rates, the size of companies and growth rates, urban dimension, scientific discoveries, the presence of a 
strong correlation in price changes, motivated by a reconsideration of a number of opinions, the distribution of income and welfare, studies on the statistical properties of growth rates, etc. (Săvoiu, 2012). The first signal likely to encourage the cross-disciplinary application of the methods and models of physics in different areas, starting with biology and economics, was publicly launched by Hideki Yukawa, Nobel Prize winner for physics in 1949. Other examples of the expansion of econophysics through interdisciplinary solutions are offered initially by Vilfredo Pareto's method, a statistical and mathematical solution to the analysis of wealth distribution in a stable economy (including the Paretian optimal value derived thence), the method of financial mathematics described by Louis Bachelier concerning the quantification of the probability of a price change, the Black \& Scholes method for evaluating the rational option for a price, etc., and subsequently through econophysical methods, the first of which belonged to economists Stigler (1964), Markowitz and Kim (1987), and to physicists Mantegna (1991) and Takayasu (1992), which, in the last decade, even produced generalized applications of physical models in distinct economic domains, known as physical investigative econo-tools.

Subsequently, more and more application areas emerged, ranging from human or demographic ones, to the behaviours of populations of increasingly diverse entities, which were obviously also subject to biological laws have also emerged. In this third paradigm of econophysics, which was initially simple and at the end of a complex nature, the evolutionary process, from interdisciplinarity to multidisciplinarity, continues to be similar and benefits from the same intensity (Figure no. 4):
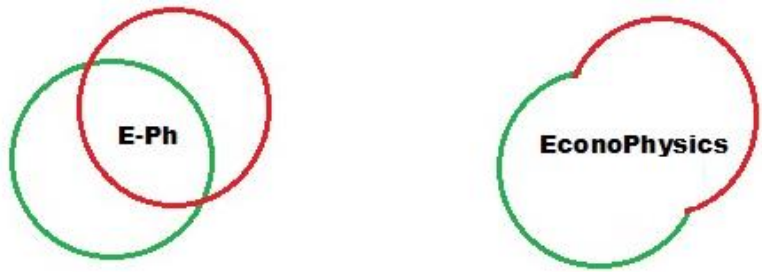

Figure no. 4: Interdisciplinary inception (left), and multidisciplinary evolution of econophysics (right)

The process of gradually changing the simple paradigm into a complex one has been completed in a multiparadigm, in the specific sense of Herbert Feigl (2004), which conduces to a superior construction by creating a completely new science, as a result of a much wider multidisciplinarity, resulting from the punctual interdisciplinarities presented above, where the dominant stresses can be found in the central part of its name (Figure no. 5). The result of the expansion of circular interdisciplinarity virtually becomes a complex multidisciplinarity, thee constructing principle and taxonomy of which are both symmetrical and iterative (Săvoiu, 2014).

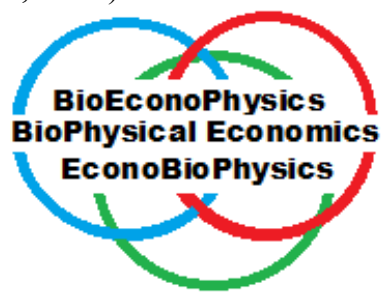

Figure no. 5: The Complex Multiparadigm of Bio-Physics-Economics (B-F-E), Econo-Bio-Physics (E-B-F), or Bio-Econo-Physics (B-E-F) 
The approach described, going from bioeconomics to bioeconophysics (economic biophysics or econobiophysics), based on language, rules of formation and comprehension, followed a general historical maturing process in modern science, being a process of conceptualization through taxonomization, focused on inter- and multidisciplinarity, as well as on Ludwig Wittgenstein's logic, in the phrase "written signs or spoken sounds have a meaning as long as they are accompanied by thoughts", further synthesized as "thoughts represent the meanings of concepts and propositions or sentences", generating the triplet to think - to understand - to use or to apply (Wittgenstein, 2001). Finally, the taxonomic reality that induces a correct choice and an appropriate future requires a selection of the third solution, argued by the article between: a) level II interdisciplinary between three interdisciplinary sciences; b) the final multidisciplinarity of three unidisciplinary sciences such as biology, economics and physics; c) multidisciplinarity following, and resulting from, the unification of three interdisciplinary sciences (bioeconomics, biophysics, econophysics). If, at the beginning of the article, the authors' preference oscillates between the notions of bioeconomics and economic biophysics, finally, as far as the name of the new multidisciplinary science is concerned, the historical arguments, the pragmatic value, the consistency and the acknowledged variety of the physical models in bioeconomics investigation, in accordance with the Nobel prizes that are more and more freqeuntly awarded to the authors of such papers and researches, entitle us to believe that, in the coming decades, it will lead to opting for bioeconophysics, despite the use of the term economic biophysics in the US (Libbs, 2016).

\section{From the relationships of science with ethics, to (bio) diversity and modern morality}

The possibly conflictive character holding between modern science and ethics was revealed, in an exaggerated and alarming manner, by George Steiner, in his book Language and Silence, five decades ago, the illustration of this lack of harmony laying stress on natural sciences (including biology) and mathematics (essential in physical modelling), two sciences whose prestige was born out of their neutrality in relation to ethics, or their noninvolvement with morality. This was the first serious signal as to the destruction, or else a large-scale, planet-wide suicide (Steiner, 1998), in connection with the imminence of three already manifested or intuited dangers: nuclear energy, genetic engineering and robotics. Thus defining a realistic trend, cautiously and under the impact of uncertainty, a group of scholars who stood certainly closer to pessimism, rather than optimism, suspended between continuity and collapse, are becoming more and more convincing in their scientific argumentation of the fact that human activities have already profoundly degraded Planet Earth and its biological equilibria in the historical leap, located temporally in 1950, from the Holocene to the Anthropocene (Waters, et al., 2016).

In contradistinction to these researchers, who no longer believe in either the economy defined by growth, or its slowing down, while calling for highly prohibitive regulations and global resource management, as they are increasingly characterized by pessimism, the group of the optimists turn into a proactive set, who are underlining the importance of the human resource and its saving creativity, substantiated by research, innovation, new technologies and new partnerships between the business environment and that of preservation and conservation, and thus represent the optimism offer (Yergin, 2012; Whiteman, Walker and Perego, 2013; Kennedy, Whiteman and den Ende, 2017). In this 
way, both the optimists and the pessimists resume the same general theme of science's relationship with ethics.

The issue of ethics was present in the science of economics, even from its birth act, placed under the paternity of Adam Smith's two major works, the first less well-known and devoted to moral philosophy, presenting its intention in its very title, i.e., building a theory of moral sentiments (Smith, 1759), and the famous investigation into the nature and causes of the wealth of nations (Smith, 1776), which simultaneously insinuated, into the fabric of the new science, both the moral dilemma (Macfie, 1959; Wilson and Gowdy, 2015), and the paradox of the theories of generosity and self-interest (Mohammadian, 2006).

If ethics with Adam Smith remains a value that can never be quantified, being naturally modelled inside homo economicus as a social being, morality, an impartial or apparent spectator, gradually and surprisingly directs or guides the individual towards a system of behavioral rules, amalgamating feelings through socially built and socially assumed experience. At the level of a classical scientific entity, such as bioeconomy or bioeconomics, ethical relations remain secluded in Adam Smith's paradox, and gradually lose their theoretical possibilities of balancing and optimizing with the help of the "invisible hand" (Butler, 2011). In modern bioeconomics, optimizing the same relationships, and adding value through holistic ethics, become a vital issue.

If, in bioeconomy, all individuals and organizations have to simultaneously meet three principles, namely a biologic (population) principle, another principle of an economic nature (the efficiency of input-output processes), and finally a physical (entropic) principle, it is found that ethics is hardly compatible with at least one of them, i.e., the physical principle, against which it would be ideal for it to remain neutral. At the same time, one can formulate arguments in connection with which the dogmatism of ethics becomes harmful in its relations with classical bioeconomics and bioeconophysics, in much the same way as the philosophical presentation of excessive caution, or excessive certainty: i) ethics proposes limits according to exclusively unfavourable or disastrous scenarios; ii) ethics maintains that the effects of restrictions are exclusively useful; iii) ethics fails to take into account the advantages of technology, and favours nature-based reasoning at the expense of humans; iv) ethics illegally transfers the evidential burden to the person who proposes the new technology or activity, always placing them in an unfavourable position; v) ethics brings about new imbalances related to risks and damages (More, 2005).

(Bio)diversity goes through two processes that simultaneously imply shrinkage of populations, through the extinction of an increasing number of species, and the individual expansion, in keeping with the dynamics of the human population and the increasing diversity of the individual, which will in the next decades achieve an extension of human uniqueness, based on DNA, reaching the level of a figure quite unimaginable two centuries ago, i.e., $10^{10}$. Classical biology and modern bioeconomists have inventoried and phased extinction rates of the species, beginning with $\mathrm{AD} 1500$, which were multiplied more than 100 times in the $20^{\text {th }}$ century, and, in 2015 , entered a sixth stage of major extinction by its scale and impact (Crânganu, 2015; 2016).

In this context, there appears a remarkable and maximally synthesizing tendency, through symmetry with the involution of species diversity, which boils down to a review of moral rules or principles, or else of morality in a general sense (Chung and Mitsuyoshi, 2017). In the attempt to synthesize the main moral aspects of the dominant religions, one comes to 
profoundly simplistic judgments, which are resonant with the need to change the relation between science and ethics. Of the ten Biblical commandments, through intersection with the moral aspects exhibited by the other great religions of the world, as few as three common moral rules can be singled out, extracted from the classic Decalogue: "Do not kill others; Do not steal from others; Do not deceive others", centered in a single rule through an ethical formulation of crystal limpidity: "Do not harm other human beings".

This integrated common rule, however, seems to have never been observed in situations such as war and capital punishment in human history, presenting an ultimate contradiction between human morality and human reality. This seemingly unsolvalbe contradiction can be consistently explained by looking at the true meaning of the words "other human beings". Although the words appear to mean "other biological human beings in general", these words in reality mean "other fellow human beings", excluding enemies and criminals. Thus, the integrated common rule should be rephrased: "Do not harm other fellow human beings." This rephrased rule has been well observed and also the efforts to observe this rule have been made in all society in human history.

On the other hand, The Decalogue contains a distinct type of rules - including "Worship only one God ('Thou shalt have no other gods before me')," "Do not make idols," and "Observe the Sabbath,"- which cannot turn into rules common to all societies. These rules are specific to a certain society, urging its members to think and behave in a manner similar to that of other fellow human beings. The Decalogue seems as if two different kinds of rules were put together: "Do not harm other fellow human beings," and "Think and behave in a manner similar to that of other fellow human beings." Is it a mere jumble of unrelated rules from different systems? No. Such coexistence - combination of different types of rules - may rather reflect the true nature of morality hidden inside.

While the two kinds of rules - common and specific - seem to be far distant from each other, we can collectively express what they tell, in a form of a single principle: " $B e$ fellowish." This is what seems to represent the true nature of morality. According to this analysis, this principle consists of two elements. The first element of the principle: "Be fellowish" tells you "not to harm other fellow human beings." In the Decalogue, rules represented by "Thou shalt not kill" correspond to what this element means. This element is supposed to be readily understandable and acceptable for everyone. Division of labor and cooperation are necessary to form and maintain any society. For this purpose, the code: "Do not harm other fellow human beings" should be observed as a minimum standard. Rules based on the first element therefore remain unchanged even if the coverage of "fellow" changes. In other words, we can call such rules "invariable standards of fellowness".

The second element of the "Be fellowish" principle tells you "to think and behave like other fellow human beings do" In the Decalogue, a subset of rules represented by "Thou shalt have no other gods before me" correspond to what this element means. These rules are, in short, standardized manuals of how to think and behave; they set certain standards to integrate ways of thoughts and behaviors among fellows. Such standardization helps to enhance fellowness. Rules based on the second element vary across religions, nations and ethnoses. In other words, those rules are "variable standards of fellowness", which change along with the coverage of "fellow". 
Now we can see the two different aspects of human morality: the first aspect is common and invariable in all human societies, while the second aspect is specific and variable with the coverage of fellow. Morality intrinsically contains duality.

The vision of such morality, which is centered on a unique principle, gives stability to diversity, neutrality in the subjectivity presupposed by the relationship between science and ethics. Outlining a common, invariable and predictable ethical content for all human communities and, at the same time, a useful and generalized content in perspective, a perfectly symmetric one-principle morality, characterized by complete reciprocity, it can represent a moral solution in both the necessary balance of humanity through inclusion rather than exclusion, and establishing the relationships between ethics and bioeconophysics, whose creativity will survive irrespective of global economic, social and legal changes (Săvoiu and Iorga, 2018).

\section{Conclusions}

Undoubtedly, neither biology, nor economics, bioeconomics, or bioeconophysics, have been, or are currently exempted from deficiencies or excesses. A major deficiency of bioeconophysics is currently the very lack of a project of parallel bio-econo-justice (BioEcoJust), which should include more than researchers and philosophers of morality, and could anticipate the decisions that have to do with the transformation of resources, the human species and the Earth. The tradition of excesses in the economy has become proverbial over time, whether we are talking about the preying Veblenian entrepreneur, or we refer to the absenteeism of property, and event o the type of Marxist egalitarian welfare.

The approach going from bioeconomics to bioeconophysics did not exclude, but rather constantly included the paradox. The dominant tendency of humans to overvalue biological systems, physical modelling and biological scientific thinking in the economy first appear in Stanley Jevons's The Question of Coal (Jevons, 1865), without however anticipating the concept of physical bioeconomics, and even less that of econobiophysics. This approach has remained in scientific memory as Jevons' paradox or effect in environmental economics. This paradox states that, when technological progress increases, the efficiency with which a resource is used, although the expectations are that these gains in efficiency will practically reduce the consumption of resources, it is found that, in actual fact, and to the detriment of governments and environmentalists, the consumption rate of that resource increases - the cause being precisely that economic demand, which is continuously expanding. The Jevons paradox was probably the best known, and implicitly the most visible paradox in today's environment economics (York, 2006).

Two and a half millennia after Socrates, and the idea of self-knowledge as the ultimate, supreme value of the individual, more or less intelligent people (intelligent in the sense of being more or less able to adapt to the natural environment and human society) want to understand ethical or moral aspects of their bioeconomic evolution, who they are in biological terms, how they have reached this economic reality, and what bioeconophysic future they and their peers (and especially their descendants) have. The pursuit of Utopia, in terms of perfect bioeconomic justice, proved, after half a century of communism/statesocialism, to be a way to hell, while the capitalism of the state focused on welfare, specific to the market economy, with its hard edges smoothed by strong security, has less to admittedly more decent societies (Wight, 2015), but the solutions for bio-economic or 
bioeconophysic optimization and inclusion are necessary now, and will certainly be needed in the future, too. Pessimistic people and organizations lacking optimism are naturally afraid of the future and can form entities for which economic welfare is not the greatest achievement of mankind, but its biggest problem (Mann, 2018), following the logic of a temporary prosperity that sets out from the desire extract and / or consume more resources than Planet Earth can give and / or regenerate, with the normally expected end of global devastation, and even its own extinction as a final result (Crânganu, 2018). Recent studies highlight the more intense exploatation of Terras natural ressources, which requires the implementation of a social responsible consumption (Crișan et al., 2016; Dabija, Postelnicu and Dinu, 2018).

If lucid (rather than merely candid or Voltairean) optimism is missing, ethics is beginning to dominate science through restrictions, and it can, historically and significantly, slow the pace of research, innovation, technology, etc. Scientific multidisciplinarity and ethics, in balanced, well-adjusted relationships, can however proide technological solutions for bioeconophysics to find that the difficult economic situations generated by resource precariousness, and even entropy of systems, can be overcome. Human welfare, culture, and education are by no means insoluble problems, but solutions to the dilemmas of the future.

\section{References}

Avicenna, 1962. Poemul medicinii. Canonul științei medicale. București: Editura medicală.

Bachelier, L., 1900. Thèorie de la spèculation. Annales Scientifiques de l'Ecole Normale Supèrieure, III(17), pp. 21-86.

Baranoff, F.I., 1918. On the question of the biological basis of fisheries. Institute for Scientific Ichthyological Investigations, Proceedings, vol.1, pp. 81-128.

Baranoff, F.I., 1925. On the question of the dynamics of the fishing industry. (In Russian) Byulleten Rybnogo Khozyaistva, vol. 5(8). pp. 7-11.

BP Economics, 2018. International Society for BioPhysical Economics [online] Available at: 〈http://bpeconomics.org/> [Accessed 23 February 2018].

BPE, 2016. BioPhysical Economics Meeting [Facebook] 22/March 2016, Available at: <https://www.facebook.com/bpeconomics/> [Accessed 23 February 2018].

Burkenroad, M.D., 1951. Some principles of marine fishery biology. Publ. Inst. Mar. Sci (Texas), 2(1), pp. 177-212.

Burkenroad, M.D., 1953. Theory and practice of marine fishery management. Journal du Conseil International pour l' Exploration de la Mer, 18(3), pp. 300-310.

Butler, E., 2011. The Condensed Wealth of Nations and The Incredibly Condensed Theory of Moral Sentiments. London: Adam Smith Institute-ASI (Research) Publisher Ltd.

Chung, U.-I., and Mitsuyoshi, S., 2017. Diversity and Morality: Crossing Borders with Engineering Approach [Kindle DX version] (Kindle edition). Amazon Services International, Inc. Available at: Amazon.co.uk <http://www.amazon.co.uk> [Accessed 12 March 2018].

Crișan-Mitra, C., Dinu, V., Postelnicu, C. and Dabija, D.C., 2016. Corporate Practice of Sustainable Development on an Emerging Market. Transformations in Business \& Economics, 15(1(37)), pp. 228-243. 
Crânganu, C., 2015. A șasea extincție a vieții pe Terra? [online] Available at: <http://www.ropepca.ro/articole/a-sasea-extinctie-a-vietii-pe-terra/130/> [Accessed 16 February 2018].

Crânganu, C., 2016. Trăim deja în Antropocen, între sustenabilitate și colaps. Ce va urma?, [online] Available at: < http://www.contributors.ro/cultura/traim-deja-in-antropocenintre-sustenabilitate-\%C8\%99i-colaps-ce-va-urma/> [Accessed 2 March 2018].

Crânganu, C., 2018. Profeți și vrăjitori: Intre eco-apocalips și tehno-optimism. [online] Available at: <http://www.contributors.ro/?p=24358> [Accessed 4 March 2018].

Dabija, D.C., Postelnicu, C. and Dinu, V., 2018. Cross-Generational Investigation of Ethics and Sustainability. Insights from Romanian Retailing. In: S.O. Idowu, C. Sitnikov, D. Simion and C. Bocean, eds. 2018. Current Issues in Corporate Social Responsibility. An International Consideration. Cham: Springer International Publishing, pp. 141-163.

Demetrescu, M.C., 1996. Filosofia matematicii în economie. In: N. Georgescu-Roegen, ed. 1996. Omul și opera. București: Editura Expert, pp. 222-225.

Dinu, V., Săvoiu, G. and Dabija, D.C., 2016. A concepe, a redacta şi a publica un articol științific. O abordare în contextul cercetării economice. București: Editura ASE.

Feigl, H., 2004. The „orthodox" view of theories: Remarks in defense as well as critique. Scientiae Studia, 2(2), pp. 265-277.

Foucault, M., 1977. Discipline and punish: The birth of the prison. Translated from the French by Alan Sheridan. New York: Vintage Books.

Frisch, R., 1933. Editor's Note. Econometrica, 1, pp. 1-4.

Georgescu-Roegen, N., 1971. The Entropy Law and the Economic Process. Cambridge, MA: Harvard University Press.

Georgescu-Roegen, N., 1977a. What thermodynamics and biology can teach economists. Atlantic Economic Journal, 5(1), pp. 13-21.

Georgescu-Roegen, N., 1977b. The Steady State and Ecological Salvation: A Thermodynamic Analysis. Bioscience, XXVII, pp. 266-270.

Gerhardsen, G.M., 1952. Production economics in fisheries. Rev. Economia, 5(1), pp. 1-12.

Gordon, H.S., 1991. The Economic Theory of a Common-Property Resource: The Fishery. Bulletin of Mathematical Biology, 53(1/2), pp. 231-252.

Ibn, K., 1969. The Muqaddimah: an introduction to history, Princeton, New Jersey: Princeton University Press.

Jevons, W. S., 1865. The Coal Question. London: Macmillan and Company.

Kennedy, S., Whiteman, G. and den Ende, J., 2017. Radical Innovation for Sustainability: The Power of Strategy and Open Innovation. Long Range Planning, 50 (6), pp. 712-725.

Libbs, T., 2016. Hmolpaedia [online] Available at: <http://www.eoht.info/ page/ BPE+2016> [Accessed 25 February 2018].

Lotka, A.J., 1925. Elements of Physical Biology. Baltimore: Williams and Wilkins Company.

Macfie, A., 1959. Adam Smith's Moral Sentiments as Foundation for His Wealth of Nations. Oxford Economic Papers, 11(3), pp. 209-228. 
Majorana, E., 1942. Valoare delle statistiche leggi nella fisica e nelle scienze. Scientia, 36 (1), pp. 58-66.

Mann, C., 2018. The Wizard and the Prophet: Two Remarkable Scientists and Their The Wizard and the Prophet: Two Remarkable Scientists and Their Dueling Visions to Shape Tomorrow's World. New York: Alfred A. Knopf.

Mantegna, R.N., and Stanley, H.E., 2000. An introduction to econophysics: correlations and complexity in finance. New York: Cambridge University Press.

McCormick, K.N., 2013. The Bioeconomy in Europe: An Overview. Sustainability, 5(6), pp. 2589-2608.

Miernyck, W., 1996. Un spirit în avans față de timpul său. In: N. Georgescu-Roegen, ed. 1996. Omul şi opera. București: Editura Expert, pp. 183-191.

Mimkes, J., 2016. Talk: Bio-Econo-Physics, Synthesis of Social and Natural Science? [online] Available at:< http://www.eoht.info/page/BPE+2016> [Accessed 25 February 2018].

Mirowski, P., 1996. Nicholas Georgescu-Roegen In: N. Georgescu-Roegen, ed. 1996. Omul și opera. București: Editura Expert, pp. 202-221.

Mohammadian, M., 2006. Bioeconomic Ethics: A New Morality for the Socioeconomic Enterprise in the Third Millennium. Journal of Interdisciplinary Economics, 17(4), pp. 379-399.

More, M., 2005. The Proactionary Principle [online] Available at: <https://web.archive. org/web/20051029124848/http://maxmore.com:80/ proactionary.htm> [Accessed on 15 March, 2018].

Nesbit, R.A., 1943. Fishery Management. Chicago, IL: U.S. Fish and Wildlife Service.

Odum, H.T., 1971. Environment, Power, and Society. New York: Wiley-Interscience.

Pierce, S. J., 1991. Subject areas, disciplines and the concept of authority. Library and Information Science Research, 13(1), pp. 21-35.

Reinheimer, H., 1913. Evolution by Co-operation: A Study in Bio-economics. London: Kegan Paul, Trench, Trubner and Co.

Săvoiu, G., ed. 2012. Econophysics: Background and Applications in Economics, Finance, and Sociophysics. London: Elsevier Academic Press.

Săvoiu, G., 2014. The impact of inter-, trans- and multidisciplinarity on modern taxonomy of sciences. Current Science, 106(5), pp. 685-690. [online] Available at: <http://www.currentscience.ac.in/Volumes/106/05/0685.pdf> [Accessed 16 February 2018].

Săvoiu, G., 2015. Statistical Thinking. The Contribution of Its Reseach Methods and Models to Modern Trans-, Inter-, and Multidisciplinarity. București: Editura Universitară.

Săvoiu, G., Dinu, V. and Tachiciu, L., 2014. An Inter-, Trans-, Cross- and Multidisciplinary Approach to Higher Education in the Field of Business Studies. Amfiteatru Economic, 16(37), pp. 707-707.

Săvoiu, G. and Iorga Simăn, I., 2018. Creativity and Morality. Econophysics, Sociophysics \& other Multidisciplinary Sciences Journal, 7(2), pp. 38-41 [online] Available at: <http://www.esmsj.upit.ro/No17_2017.html > [Accessed 2 March, 2018] 
Steiner, G., 1998. Language \& Silence: Essays on Language, Literature \& the Inhuman. 11th ed. New Haven: Yale University Press.

Stichweh, R., 2001. Scientific Disciplines, History of. In: N.J. Smelser and P.B. Baltes, eds. 2001. International Encyclopedia of the Social and Behavioral Sciences. Oxford: Elsevier Science, pp. 13727-13731.

Tache, A., 1968. Figuri ilustre din Evul mediu. București: Editura Tineretului.

Taylor, H.F., 1951. Survey of marine fisheries of North Carolina. Chapel Hill: Univ. N.C. Press.

Waters, C. N., Zalasiewicz, J. Summerhayes, C., Barnosky, A. D., Poirier, C., Gałuszka, A., Cearreta, A., Edgeworth, M., Ellis, E. C., Ellis, M., Jeandel, C., Leinfelder, R., McNeill, J. R., deB. Richter, D., Steffen, W., Syvitski, J., Vidas, D., Wagreich, M., Williams, M., Zhisheng, A., Grinevald, J., Odada, E., Oreskes, N., Wolfe, A. P., 2016. The Anthropocene is functionally and stratigraphically distinct from the Holocene. Science, 351(6269), pp. 137-138.

Whiteman, G., Walker, B. and Perego, P., 2013. Planetary boundaries: Ecological foundations for corporate sustainability. Journal of Management Studies, 50(2), pp. 307-336.

Wight, J.B., 2015. Bioeconomics and Ethics. Economics and Ethics, [online] Available at: <http://www.economicsandethics.org/2015/03/bioeconomics-and-ethics.html> [Accessed 17 February 2018].

Wilson, D.S. and Gowdy, J.M., 2015. Human ultrasociality and the invisible hand: foundational developments in evolutionary science alter a foundational concept in economics. Journal of Bioeconomics, 17(1), pp. 37-52.

Witt, U., 1999. Bioeconomics as Economics from a Darwinian Perspective. Journal of Bioeconomics, 1(1), pp. 19-34.

Wittgestein, L., 2001. Tractatus Logico-Philosophicus. București: Editura Humanitas.

Yergin, D., 2012.The Quest: Energy, Security, and the Remaking of the Modern World. New York: Penguin.

York, R., 2006. Ecological paradoxes: William Stanley Jevons and the paperless office. Human Ecology Review, 13 (2), pp. 143-147. 